\title{
The Relationships Among Four Factors and Turnover Intentions at Different Levels of Perceived Organizational Support
}

\author{
Thanawatdech Thirapatsakun, Chanongkorn Kuntonbutr, Panisa Mechida \\ Rajamangala University of Technology, Thanyaburi, Thailand
}

\begin{abstract}
The last few years have confirmed what was mostly feared: Thai private hospitals industry has affected from a shortage of professional nurses and turnover intention. This paper occurs mainly about the relationships among four factors and turnover intention at different levels of perceived organizational support are clarify for the mentioned above. The sample was 890 professional nurses who obtain a professional nurse license and are entitled to perform their work in hospitals in Thailand. The results revealed that three components job demand, work schedule flexibility, and financial reward, best explained turnover intention. The result indicated that job demand had an influence on turnover intention through work engagement. Moreover, perceived organizational support had an effect on turnover intention through work engagement. Additionally, there was insignificant difference in terms of the fit of the structural models for the high and low level of perceived organizational support, indicating there is no moderating effect of perceived organizational support on the relationship between job demand and work engagement. This paper synthesizes some suggestion and discusses the relationships among four factors and turnover intention at different level of perceived organizational support to improve to reduce causing and affecting of worker shortage and turnover intention.
\end{abstract}

Keywords: context of different levels, perceived organizational support, turnover intention

Since 2005, the Thai private hospitals industry has faced significant effects from a shortage of professional nurses and turnover intention. Meanwhile, the government has promoted Thailand as the regional center of excellent health care and as the medical hub in Asia, and the Thai private hospitals industry benefits from the 2015 launch of the Asian Economic Community (AEC). Regarding medical tourism in Thailand, the volume of international patients traveling to Thailand increased by $16 \%$ and generated US\$ 1.3 billion in 2007, with a prediction of US\$ 4.3 billion in 2012 (Kanchanachitra et al., 2012, p. 775). However, while the annual increase of $16 \%$ in international patients is maintained during 2005 to 2015 , the private sector needs 49,991 nurses (Pagaiya \& Noree, 2009). Thailand has well-positioned itself to become the medical hub of Asia, with at least

Corresponding author: Thanawatdech Thirapatsakun, Ph.D., Managing Director of Thayawat Engineering and Construction Co., Ltd., special instructor in Faculty of Business Administration, Rajamangala University of Technology, Thanyaburi, Thailand; research fields: quality work, high performance work systems, turnover intention, productivity management, Energy Management System Audit, construction management, and employment relation and regulation in Thailand. E-mail: thanawat8@hotmail.com.

Chanongkorn Kuntonbutr, D.B.A., associate professor, dean, Faculty of Business Administration, Rajamangala University of Technology, Thanyaburi, Thailand; research fields: international business and international management, industrial relations, employment relation, and labour regulation in Thailand. E-mail: Ck959@yahoo.com.

Panisa Mechida, Ph.D., associate professor, Faculty of Business Administration, Rajamangala University of Technology, Thanyaburi, Thailand; research fields: organizational performance and employee well-being, and tourism marketing strategy in Thailand. E-mail: mechinda.panisa@gmail.com. 
400 hospitals of which 130 private general hospitals are in the Bangkok area and 299 private general hospitals are in the urban area (Ministry of Public Health, 2005). The term "medical tourism" describes tourists who travel overseas to obtain healthcare, dental, and surgical care while having the opportunity to combine it with visiting tourist attractions of that country. In 2004, Thailand's Government adopted a five-year strategic plan to develop the country into the "Center of Excellent Health of Asia". This strategic plan, advanced by the Ministry of Public Health, concentrated on three main areas of health care: (1) medical service and healthcare services which include spa and traditional massages; (2) long-stay healthcare products and services; and (3) Thai herbal product [The Thai Board of Investment (BOI) Review]. Due to an approval of the strategic plan to develop Thailand, it aims to promote the related sectors consisting of medical care service, health promotion tourism, and Thai herbal and health products. The core business of the medical care service in the private hospital sector has now more than a hundred private hospitals that is able to accommodate foreign customers all over the country. Medical tourism is defined to people traveling as being able to obtain medical care service in a standard hospital or medical center. The activities include treatments, health prevention, and health rehabilitation (e.g., physical check-ups, medical treatments, dentistry, cosmetics surgery, and transsexual surgery). The target areas are divided into three based on the characteristics of a potential in terms of tourism and medical care service. The potential private hospitals refer to the hospitals which fulfill the criteria such as providing medical care services with modern medical equipment and technology by the specialists/doctors and providing convenient and quick services with hospitality. In addition, these private hospitals have the potential to accommodate foreign tourists with persons to provide assistance (i.e., interpreter and the foreign client care staff) and the facilities such as comfortable rooms, international foods, multimedia, and communication systems.

Based on several reports, however, it is clear that the nursing profession in Thailand is in crisis. The problems concerning the nursing practice include the work environment, remuneration, and opportunities for advancement. Some private hospitals also suffer from shortages of personnel, because many nurses leave for continuing education, resign as a result of dissatisfaction with their welfare or the administration, or pursue jobs in other fields (Srisuphan et al., 1998). Simones, Villeneuve, and Hurst (2005) noted that the nursing shortage appears to be caused by several factors including fewer young people entering the work force, the low social value of nursing, and the negative perception of the working conditions of nurses. Additionally, nurses perceive an increase in job stress. At the same time, there is an increasing importance of new employees, acknowledgment of advancements in technology, globalization, demographic trends, constantly changing work roles, and expectations along with increasing work demands, which could lead to work overload, job dissatisfaction, and job stress (Beehr \& Glazer, 2005). Thus, employers are exploring various incentive strategies to improve retention of their workforce and to support employees' growth aspirations. This study was conducted to investigate the factors that decrease turnover.

This study contributes to the existing literature on the relationships among job demands, work engagement, work schedule flexibility, financial reward, and turnover intentions in the context of different levels of perceived organizational support and addresses strategic implications for practitioners. First, this study examined job demand, work engagement, work schedule flexibility, and financial reward on turnover intentions. These factors may influence different levels of perceived organizational support that is moderated between job demand and work engagement, both of which are crucial for practice and gap areas of research. Second, the study provides better understanding of the perceived organizational support that may be an extrinsic motivator 
to employees because it fosters employee engagement, creating low-level turnover intention.

Another purpose of this study was to examine perceived organizational support as a possible moderating variable with multi-group equivalent applications for determining a measurement that operates equally across the different populations of the group in the model approach.

\section{Literature Review}

There is an abundance of research that aims to explain the relationships among job demand, work engagement, work schedule flexibility, financial reward, and turnover intentions in the context of the different levels of perceived organizational support. Employees who have to work increasingly long work hours may have different work and leisure expectations, but according to one article, employees want to work fewer working hours (Major, Klein, \& Ehrhart, 2002). Furthermore, long working hours may result in other negative effects, such as trouble in balancing home and work life leading to psychological distress (burnout), decreased performance, and decreased job satisfaction (Frone, Russell, \& Barnes, 1996; Major et al., 2002). Work schedule flexibility enhances employees' quality of life at work and lessens the degree to which work and family roles conflict (Baltes, Briggs, Huff, Wright, \& Neuman, 1999; Major et al., 2002). In addition, Rosin and Korabik (2002) found work schedule flexibility is beneficial in motivating employees, particularly in high performing professions, and can decrease turnover. Hence, hypothesis 1 (H1) was formulated as follows:

H1: Work schedule flexibility has a negative effect on an employee's turnover intention.

According to the index of organizational reactions (IOR), Kahn and Byosiere (1992) found that employees would feel obligated to continue to work if the organization did not provide financial rewards or compensation for their resources and benefits, and employees are more likely to disengage from their work role. Rhoades, Eisenberger, and Armeli (2001) found that if employees did not receive fair and just rewards, they would withdraw and disengage from the organization. Financial reward systems are particularly useful for controlling the turnover of employees who are high performers, because the more rewards provided under an employee performance contingent system the more satisfied and less likely to leave these employees would be (Allen \& Griffeth, 2001). Without performance contingent rewards, the relationship between financial rewards and turnover intention becomes positive such that individuals who are not rewarded are much more likely to leave rather than employees who are rewarded. While this may be true, there may be many factors that cause turnover, not just financial rewards (Trevor, Gerhart, \& Boudreau, 1997). In addition, based on the workplace culture, rewards for task completion show high satisfaction and low turnover and are indicators of the desire of employees to stay in a workplace (March, Guetzkow, \& Simon, 1958). The rationale and evidence provided in the earlier studies led to hypothesis 2 (H2), as follows:

H2: Financial reward has a negative effect on an employee's turnover intention.

Maslach and Jackson (1986) supported the hypothesis that states that the presence of specific demands (work overload and personal conflicts) predicts burnout and dissatisfaction, which increases turnover. When employees are stressed and have personal conflicts within their jobs, they experiences burnout or health problems. These situations caused them to leave their organization. Based on these ideas, the hypothesis 3 (H3) was formulated as follows:

H3: Job demand (JD) is positively related to turnover intention (TI).

Demerouti and Cropanzano (2010) as well as Schaufeli and Salanova (2007) supported the idea that engagement is associated with employees' positive attitude, proactive job behaviors, higher levels of 
psychological well-being, and increased individual job and organizational performance. These factors decrease turnover intention. Moreover, Demerouti, Bakker, Nachreiner, and Schaufeli (2001) conducted a study of employees with high work demands and controlled for the presence of high time pressure and higher levels of engagement. Job demands were positively related to burnout and disengagement (Schaufeli \& Bakker, 2004). In addition, Hu, Schaufeli, and Taris (2011) and Llorens, Bakker, Schaufeli, and Salanova (2006) found that job demands were negatively associated with work engagement. Low job demands may have a positive effect on engagement. Harter, Schmidt, and Hayes (2002) supported the finding that engagement levels were positively correlated with business unit performance and the level of turnover intention of employees. Thus, hypothesis 4 (H4) was expressed as follows:

H4: The relationship between job demands (JD) expressing negative turnover intention (TI) are mediated by work engagement (WE).

Perceived organizational support is defined as the extent to which employees perceived how an organization values an employee's contributions and cares about his or her well-being (Eisenberger, Huntington, Hutchinson, \& Sowa, 1986). Bishop, Scott, and Burroughs (2000) supported the idea that organizational support can positively influence organizational commitment and thus reduce turnover intention. Moreover, Rhoades et al. (2001) stated that perceived organizational support and affective organizational commitment are associated with significant reductions of voluntary turnover. In addition, Stinglhamber and Vandenbergehe (2003) also stated that perceived organizational support is able to reduce turnover. Some investigators proposed that perceived organizational support heightens performance, decreases absenteeism, and reduces the possibility of employees quitting their jobs (Mowday, Porter, \& Steers, 1982; Eisenberger et al., 1986). According to Kahn (1990), a supportive environment allows employees to experiment and try new things and even to fail without fearing the consequences. In addition, perceived organizational support may lead to positive effects through employee engagement (Sak, 2006). Employees will likely be more committed to the organization than when they do not perceive organizational support (Dessler, 1999). As a result, hypothesis 5 (H5) was formulated as follows:

H5: The relationship between perceived organizational support (POS) and turnover intention (TI) is negative and is mediated by work engagement (WE).

Kahn (1992) supported underlying variables related to or linked with $\mathrm{H} 4$ and stated that perceived organizational support as a moderating variable can be generalized from psychological safety involving a sense of being that is able to exhibit and employ the self without negative consequences. Moreover, Sak (2006) stated that perceived organizational support might lead to positive consequences through an employee's engagement. Hence, hypothesis 6 (H6) was expressed as follows:

H6: Perceived organizational support (POS) moderates the relationship between job demands (JD) and work engagement (WE) such that the relationships between transformational and transactional behaviors are related to job demands (JD) and to work engagement (WE).

Benchmarks in the literature have focused on the models of the antecedents of work engagement that occur when an employer experiences the suitable blend of workload, control, reward, sense of community fairness, and value congruence (Maslach, 1998). Possible positive consequences of engagement for an organization include outcomes such as increased profit and productivity, increased customer satisfaction, decreased turnover, and a sense of employee well-being with a higher job score (Harter et al., 2002). In addition, 
the research of Schaufeli and Bakker (2004), Hallberg and Schaufeli (2006), and Sak (2006) supported the relationship between engagement and turnover intentions (i.e., work engagement negatively predicted an intention to leave). However, there is a relationship between engagement and turnover where an employee with low engagement is considered to be a "threat" to the organization and has a high risk of turnover (Gostick \& Elton, 2007). Thus, the hypothesis 7 (H7) was constructed as follows:

H7: Work engagement (WE) has a significant negative relationship to the outcome variables of turnover intention (TI).

\section{Methodology}

The research method is quantitative. Specifically, this study examined the associated hypotheses for different variables. Figure 1 illustrates the conceptual framework of the study.

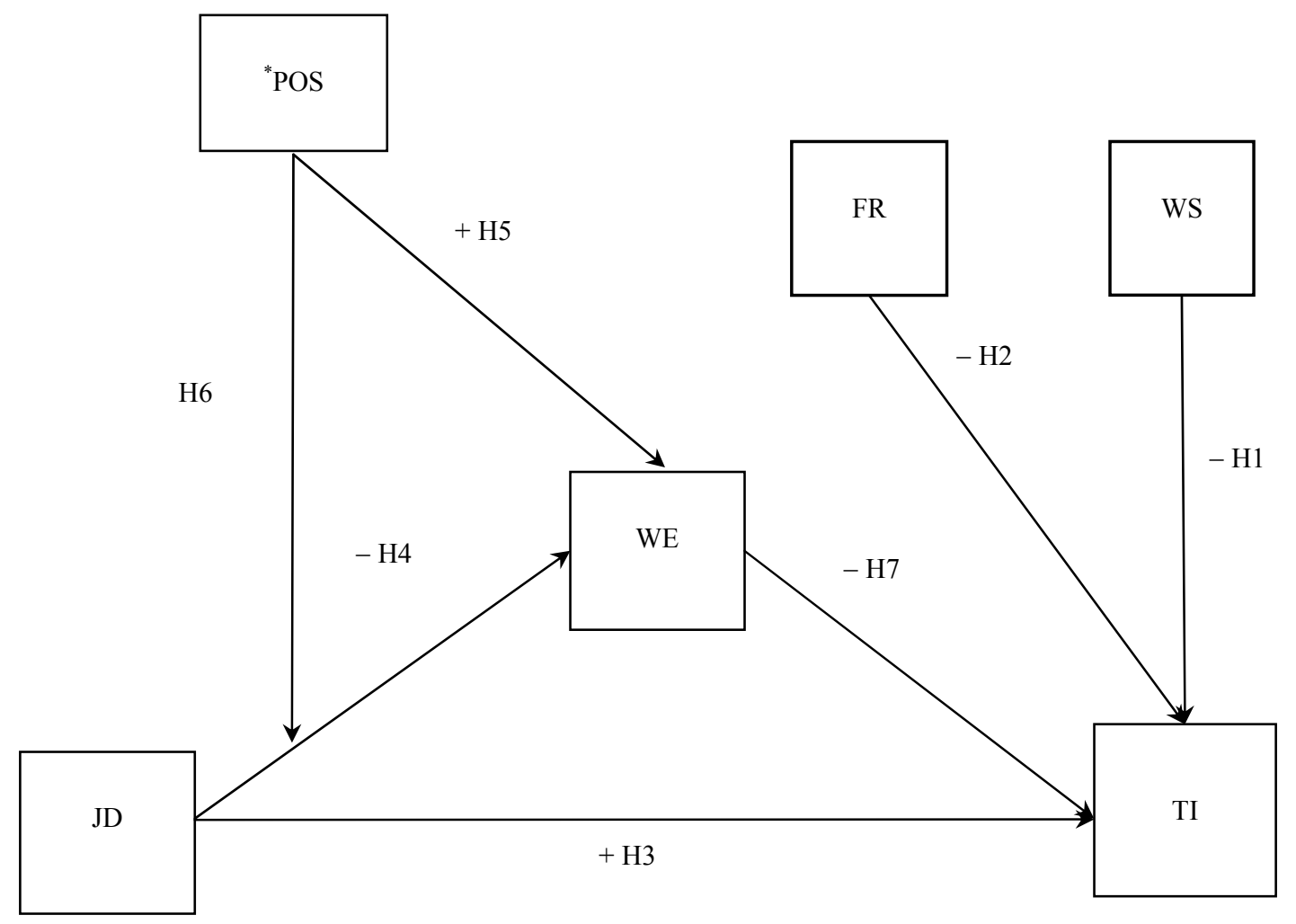

Figure 1. The conceptual framework. Notes. POS—Perceived Organizational Support, JD—Job Demand, WE-Work Engagement, TI-Turnover Intention, WS-Work Schedule Flexibility, FR—Financial Reward; ${ }^{*}$ a comparison of the POS of a professional nurse group (low level and high level of POS groups).

\section{Research Design}

The data used to test the hypotheses were collected from a sample of 890 professionals who had worked in the private health care service sector (medium and large sized hospitals with more than 51 beds) of medical tourism in Thailand. To ensure valid and reliable research procedures, on site interviews were conducted with 40 volunteers during participation in a pre-test phase. Responses to closed-ended questions using a 7-point Likert scale survey were analyzed, and then, the statistical relationships were determined. 


\section{Measurement of Variables (Exogenous, Endogenous)}

Data were collected from questionnaires with eight sections consisting of personal demographics and work status, job demands, work engagement, perceived organizational support, turnover intention, work schedule flexibility, and financial reward. The 9-item scale in the perceived organizational support section is based on unidimensionality of Eisenberger et al.'s (1986) scale. Cronbach's alpha for this scale was 0.90 (Rhoades \& Eisenberger, 2002). The 26-item scale in the job demand section was adopted from the job content questionnaire (JCQ) of Karasek's (1985) scale. Cronbach's alpha for this scale was estimated ranging from 0.61 to 0.71 (Karasek et al., 1998). The 17-item scale of the work engagement scale was adopted from the Utrecht Work Engagement Scale (UWES) developed by Schaufeli, Martinez, Marques Pinto, Salanova, and Bakker (2002). Cronbach's alpha for this scale ranged from 0.90 to 0.92 (Schaufeli \& Bakker, 2004). The turnover intention scale refers to an anticipated leaving job behaviors scale and was measured by a questionnaire. The questionnaire consisted of 14 items, and prior research demonstrated the reliability of Cronbach's alpha coefficient of 0.91 (Roodt \& Jacobs, 2008). In addition, according to the control variable section, the 5-item scale in the work schedule flexibility was assessed using Rothausen's (1994) questionnaire. Cronbach's alpha coefficient of this scale was 0.91 . The financial rewards factor of the Index of Organizational Reactions (IOR) identifies the employer's position on the relationship of job performance and the amount of money received based on responses to items 33 to 37 of the survey instrument (Cook, Hepworth, Wall, \& Warr, 1981). The reliability of the internal consistency factors ranged from 0.68 to 0.91 .

\section{Sequence of Analysis}

Part 1: To test six proposed hypotheses ( $\mathrm{H} 1, \mathrm{H} 2, \mathrm{H} 3, \mathrm{H} 4, \mathrm{H} 5$, and $\mathrm{H} 7)$, descriptive analysis, confirmatory factor analysis (CFA), and structural equation modeling (SEM) were performed. The results are reported in the result section.

Part 2: To test the last proposed hypothesis (H6), a conceptual model illustration of moderation was considered. To conceptualize the model, multiple group analysis was conducted to examine whether the different level of perceived organizational support plays a role as a moderator between job demands and work engagement.

\section{Results}

\section{Respondent Profile}

Data were collected from February to April 2013. A total of 890 questionnaires from 44 private hospitals were returned. The respondents' profile is in Table 1.

\section{Descriptive Analysis}

The results illustrated the Cronbach's alpha of the research variables ranged from 0.85 to 0.92 , indicating good reliability (Fornell \& Larcker, 1981).

\section{Confirmation Factor Analysis}

CFA was performed to confirm scale validity and reliability. In testing the model, six latent constructions were included representing the full hypothesized model. All of these constructions were tested by using the SEM program. The results revealed that all of the factor weights were significant $(p<0.05)$. The results of adaptability were $\chi^{2}=770.583, \mathrm{df}=300, \chi^{2} / \mathrm{df}=2.569$, RMSEA (Root Mean Square Error of Approximation) 
$=0.042$, NFI $($ Normed Fit Index $)=0.962$, SRMR $($ Standardized Root Mean Square Residual $)=0.086$, and CFI (Comparative Fit Index) $=0.976$. The values were below the model adaptability, as suggested by referring to $\chi^{2} / d f \leq 3, R M S E A \leq 0.070, N F I \geq 0.090, S R M R \leq 0.080 ; C F I>0.90$, which indicated a better fit (Byrne, 2001). The study removed items with factor weights less than 0.7 . The results indicated that the modified model achieved an acceptable standard, as shown in Table 2. Table 2 illustrates that the composite reliability ranged from 0.844 to 0.953 , which was higher than the standard of 0.7 . For the convergent and discriminant validity of the questionnaire, the average variance extracted (AVE) values ranged from 0.56 to 0.78 , which was higher than 0.50 . Therefore, the convergent validity of the measurement scale was acceptable. The results showed that all AVE estimates were greater than the corresponding interconstructs squared correlation estimate. In conclusion, the measurement scale had discriminant validity (Fornell \& Larcker, 1981).

Table 1

Respondents' Profile

\begin{tabular}{|c|c|c|c|}
\hline Item & Category & Count & Percentage $(\%)$ \\
\hline \multirow{2}{*}{ Gender } & Female & 875 & 98.31 \\
\hline & Male & 15 & 1.69 \\
\hline \multirow{4}{*}{ Age } & Under 30 years old & 493 & 55.39 \\
\hline & $30-40$ years old & 330 & 37.1 \\
\hline & $40-50$ years old & 55 & 6.17 \\
\hline & Over 50 years old & 12 & 1.34 \\
\hline \multirow{3}{*}{ Marital status } & Single & 609 & 68.43 \\
\hline & Married & 263 & 29.55 \\
\hline & Divorce/Widowed & 18 & 2.02 \\
\hline \multirow{3}{*}{ Education } & Nursing diploma & 22 & 2.47 \\
\hline & Bachelor's degree & 840 & 94.38 \\
\hline & Higher than a bachelor's degree & 28 & 3.15 \\
\hline \multirow{4}{*}{$\begin{array}{l}\text { Years of working } \\
\text { experience in nursing }\end{array}$} & Less than 1 year & 78 & 8.76 \\
\hline & $1-5$ years & 369 & 41.46 \\
\hline & $5-10$ years & 258 & 28.99 \\
\hline & More than 10 years & 185 & 21.79 \\
\hline \multirow{4}{*}{$\begin{array}{l}\text { Years of working at the } \\
\text { hospital }\end{array}$} & Less than 1 year & 169 & 18.99 \\
\hline & $1-2$ years & 156 & 17.53 \\
\hline & $2-5$ years & 264 & 29.66 \\
\hline & More than 5 years & 301 & 33.82 \\
\hline \multirow{5}{*}{ Department } & Intensive care unit (ICU)/Emergency room (ER) & 42 & 4.72 \\
\hline & Pediatrics or mother and child & 151 & 16.97 \\
\hline & Surgery & 183 & 20.56 \\
\hline & Internal medicine & 356 & 40 \\
\hline & Other & 158 & 17.75 \\
\hline \multirow{4}{*}{ Current position } & Registered nurse & 797 & 89.55 \\
\hline & Senior registered nurse & 16 & 1.8 \\
\hline & Head/Division head & 38 & 4.27 \\
\hline & Others & 39 & 4.38 \\
\hline
\end{tabular}


Table 2

Results of the Confirmation Factor Analysis

\begin{tabular}{|c|c|c|c|}
\hline Construct & $\begin{array}{l}\text { Standardized } \\
\text { factor loadings }\end{array}$ & $\begin{array}{l}\text { Composite } \\
\text { construct } \\
\text { reliability }\end{array}$ & $\begin{array}{l}\text { Average } \\
\text { variance } \\
\text { extracted }\end{array}$ \\
\hline 1. Financial rewards & & 0.933 & 0.78 \\
\hline For the work I do, I feel that the amount of money I make is & 0.899 & & \\
\hline To what extent are you needs satisfied by the pay and benefits you receive & 0.938 & & \\
\hline Considering what it costs to live in this area, my pay is & 0.880 & & \\
\hline $\begin{array}{l}\text { Does the way that pay is handled here make it worthwhile for a person to } \\
\text { work especially hard }\end{array}$ & 0.811 & & \\
\hline 2. Work schedule flexibility & & 0.892 & 0.67 \\
\hline The ability to take time off to be with my family as needed & 0.754 & & \\
\hline $\begin{array}{l}\text { The opportunity to perform part-time or flextime work without being } \\
\text { penalized }\end{array}$ & 0.871 & & \\
\hline The amount of flexibility in the work schedule & 0.902 & & \\
\hline 3. Job demands & & 0.933 & 0.77 \\
\hline My supervisor is concerned about the welfare of those under him & 0.938 & & \\
\hline My supervisor pays attention to what I am saying & 0.843 & & \\
\hline My supervisor is helpful in getting the job done & 0.841 & & \\
\hline My supervisor is successful in getting people to work together & 0.904 & & \\
\hline 4. Perceived organizational supports & & 0.953 & 0.77 \\
\hline Help is available from the organization when I have a problem & 0.881 & & \\
\hline The organization really cares about my well-being & 0.879 & & \\
\hline $\begin{array}{l}\text { The organization is willing to exert itself to help me perform my job to the } \\
\text { best of my ability }\end{array}$ & 0.900 & & \\
\hline The organization cares about my general satisfaction at work & 0.882 & & \\
\hline The organization cares about my opinions & 0.866 & & \\
\hline The organization takes pride in my accomplishments at work & 0.870 & & \\
\hline 5. Work engagement & & 0.884 & 0.60 \\
\hline At my job, I feel strong and vigorous & 0.716 & & \\
\hline I am enthusiastic about my job & 0.751 & & \\
\hline My job inspires me & 0.744 & & \\
\hline I feel happy when I am working intensely & 0.806 & & \\
\hline I am proud on the work that I do & 0.735 & & \\
\hline 6. Turnover intentions & & 0.844 & 0.56 \\
\hline Sent copies of your resume to prospective employer & 0.706 & & \\
\hline $\begin{array}{l}\text { Contracted an employment agency or executive search firm to obtain a job } \\
\text { with another organization }\end{array}$ & 0.753 & & \\
\hline Went on a job interview & 0.780 & & \\
\hline Talked to co-workers about getting a job in another organization & 0.761 & & \\
\hline Made any telephone inquiries to prospective employers & 0.879 & & \\
\hline
\end{tabular}

\section{Structural Equation Model}

The study used SEM to investigate the relationships among constructs. The results of adaptability were $\chi^{2}$ $=831.972, \mathrm{df}=319, \chi^{2} / \mathrm{df}=2.608, \mathrm{RMSEA}=0.043, \mathrm{NFI}=0.962, \mathrm{SRMR}=0.085$, and $\mathrm{CFI}=0.976$, which indicate a better fit (Byrne, 2001). The relationships among the key variables produced a standardized 
coefficient, a standard error, and a critical ratio that was significant at $p<0.05$. The summary of the regression weights for the model is presented in Figure 2, which shows the path results of the research model.

\section{The Moderation Effect Test}

The moderation effect for the underlying variable of perceived organizational supports was tested. To examine whether perceived organizational support moderates between job demands (JD) and work engagement (WE), a multiple group structural equation model was conducted. The data were divided into two groups, including: (1) the low level of perceived organizational support; and (2) the high level of perceived organizational support, based on the median of values of perceived organizational support. Then, those two groups were tested to investigate whether their measurement models were different. If the measurement models were different, it could be concluded that the two models are different. To test the multiple group invariance, the initial step (the model configuration) requires that the same number of factors and the factor loading pattern should be the same across the groups. Thus, the same parameters estimated in the baseline model for each group were estimated in the multiple group models separately (Byrne, 2010). This model was tested as a multiple group representation of the baseline models. Accordingly, the model incorporated the baseline models for the high level of perceived organizational support and the low level of perceived organizational support within the same file. Considering the model assessment, the goodness-of-fit statistics for this multiple group model was reported.

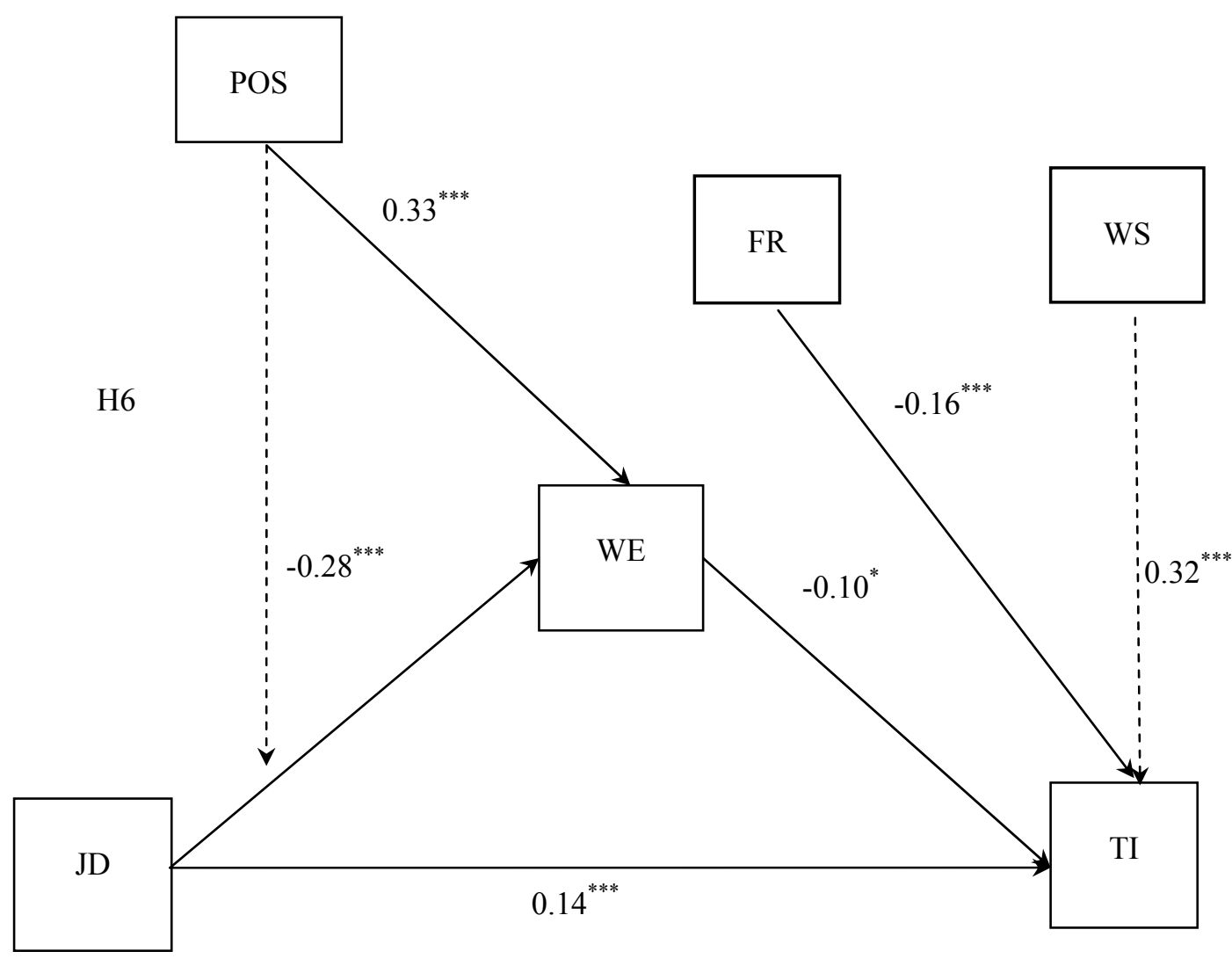

Figure 2. Path results of the research model. Notes. $\longrightarrow$ indicates that the result was supported by hypothesis testing, - - $>$ indicates that the result was not supported by hypothesis testing; ${ }^{*} P<0.05,{ }^{* * *} P<0.001$. 


\section{Multiple Group Models of CFA for Testing Moderation Effect Analysis of Multiple Groups Invariance}

Step 1: Testing for the validity of the hypothesized model across the high and low levels of perceived organizational support.

\section{Model Assessment of Step 1}

The goodness-of-fit statistics related to the two unconstrained group models (Model 1) were reported in Table 3. The chi-square value of 1,187.979, with 600 degrees of freedom, provided the baseline values with which the subsequent tests for invariance may be compared. The values of CFI and RMSEA were 0.955 and 0.033 , respectively, were determined for the hypothesized six factor model. The result represented a relatively good fit across the two panels of perceived organizational support.

Step 2: Testing for invariance of the fit for the fully constrained model across the high and low levels of perceived organizational support.

\section{Model Assessment of Step 2}

Goodness-of-fit statistics related to this constrained two groups model (Model 2) were presented as the second entry in Table 3. By testing the invariance of this constrained model, the chi-square value of 1,373.071 (with 642 degrees of freedom) was compared with that of the initial model (Model 1) in which no equality constraint was imposed. Meanwhile, the chi-square difference value of 185.92 with 42 degrees of freedom was greater than 58.124, indicating a statistically significant difference $(p<0.05)$, however, some equality constraints did not hold across the two groups.

Step 3: Testing for the invariance of factor loading across the high and low levels of perceived organizational support.

\section{Model Assessment of Step 3}

As indicated in Table 3, the results revealed that the entire factor loading should be equivalent across the high and low levels of perceived organizational support, as reflected in the significant chi-square difference between the test model (Model 3) and Model 1. The chi-square value of 1,226.929 (with 621 degrees of freedom) was compared with a chi-square value of 1,187.799 (with 600 degrees of freedom) of the initial model (Model 1) in which no equality constraints were imposed. The results were compared and revealed that the Chi-square difference value of 39.13 with 21 degrees of freedom was more than 32.671, indicating a statistically significant difference $(p<0.05)$. Based on this result, some equality constraints did not hold across the two groups.

Step 4: Testing for the invariance of factor variance and covariance across the high and low levels of perceived organizational support.

\section{Model Assessment of Step 4}

As shown in Table 3, the results from estimating Model 4 yielded a chi-square of 1,614.832 with 678 degrees of freedom. Therefore, the difference of chi-square values between this model and Model 1 was statistically significant $(p<0.05)$. The comparison of results revealed that the chi-square difference values of 427 with 78 degrees of freedom were more than 99.617. This indicated a statistically significant difference ( $p<$ 0.05). Overall, the test results of the group invariance across the four models showed that multiple groups were statically significant. This difference value was distributed as a chi-square with degrees of freedom. Evidence of no invariance is claimed if this chi-square difference value is statistically significant (Byrne, 2010). 
Table 3

Multiple Group Models of CFA for Testing the Moderation Effect Analysis of the Low and High Perceived Organizational Support

\begin{tabular}{|c|c|c|c|c|c|c|c|c|c|c|}
\hline \multirow[b]{2}{*}{ Stage } & \multirow[b]{2}{*}{ Model description } & \multicolumn{6}{|c|}{ Model fit measures } & \multicolumn{3}{|c|}{ Model difference } \\
\hline & & $\begin{array}{l}\text { Comparative } \\
\text { of model }\end{array}$ & Chi-square & $\mathrm{df}$ & RMSEA & CFI & $P$-value & $\begin{array}{l}\text { Difference } \\
\text { in chi-square }\end{array}$ & $\begin{array}{l}\text { Difference } \\
\text { in df }\end{array}$ & Sig. \\
\hline & High level of POS & - & 563.252 & 300 & 0.046 & 0.957 & 0.000 & - & - & - \\
\hline & Low level of POS & - & 624.772 & 300 & 0.048 & 0.952 & 0.000 & - & - & - \\
\hline 1 & $\begin{array}{l}\text { Unconstrained model } \\
\text { (Baseline Model 1) }\end{array}$ & - & $1,187.979$ & 600 & 0.033 & 0.955 & 0.000 & - & - & - \\
\hline 2 & $\begin{array}{l}\text { Structural covariance model } \\
\text { (factor loading, variance, } \\
\text { covariance, Model 2) }\end{array}$ & $1-2$ & $1,373.071$ & 642 & 0.036 & 0.943 & 0.000 & 185.092 & 42 & Sig. \\
\hline 3 & $\begin{array}{l}\text { Measurement weights model } \\
\text { (factor loading, Model 3) }\end{array}$ & $1-3$ & $1,226.929$ & 621 & 0.033 & 0.953 & 0.000 & 39.13 & 21 & Sig. \\
\hline 4 & $\begin{array}{l}\text { Measurement residuals model } \\
\text { (invariance uniqueness) }\end{array}$ & $1-4$ & $1,614.832$ & 678 & 0.039 & 0.928 & 0.000 & 427 & 78 & Sig. \\
\hline
\end{tabular}

Note. Sig.--Significant.

\section{Analysis of the Full Measurement of Multiple Groups}

To assess the difference between the low and high level perceived organizational support groups, a parameter-constrained path between job demand and work engagement factors were tested, and the multiple sample model was estimated. A constrained model estimated the relationship (between job demand and work engagement path factors) compared with the differences between low and high level perceived organizational supports. An interaction effect is significant if the change in the chi-square value is significant. Between the high and low perceived organizational support groups, the unconstrained model provided a chi-square value of 1,257.116 with 648 degrees of freedom. This indicated that the chi-square value and degrees of freedom are equal for the models estimated separately for the two groups (Byrne, 2004). The model with equality constraints on the one common relationship provided a chi-square value of $1,258.452$ with 649 degrees of freedom, and as a result, the hypothesis that these relationships were invariant across the two sample groups was rejected as shown in Table 4. According to the table of the critical value of chi-square, a critical value at an alpha of 0.05 and a degree of freedom of 1 is equal to $3.48(1.33<3.84)$, which was not statistically significant. Thus, the difference is statistically significant at a level greater than 0.05 , and the results revealed that all of the measurements of perceived organizational support function in the same direction for both groups. This means perceived organizational support has no moderating impact on the relationships of $\mathrm{H} 6$.

Table 4

Testing the Moderating Influence Analysis of Low and High Perceived Organizational Supports

\begin{tabular}{|l|l|}
\hline Parameter constructs & The change in the chi-square values and $\mathrm{df}$ \\
\hline Unconstrained model (all path in model) & Chi-square $=1,257.116$ with $\mathrm{df}=648$ \\
\hline $\begin{array}{l}\text { Constrained model } \\
\text { (only relationship of job demand and work engagement path) }\end{array}$ & Chi-square $=1,258.452$ with $\mathrm{df}=649$ \\
\hline Difference in chi-square values & $\Delta \chi^{2}=1.336, \mathrm{df}=1(P>0.05)$ \\
\hline
\end{tabular}

Note. Constrained refer to the restriction of the beta coefficient to be equal between the high and low moderator groups. 


\section{Discussion of the Findings Across the Hypotheses and Implications for Practice}

The findings were synthesized across the hypotheses as follows. The results revealed that the path showed a positive effect on turnover intention and was significant, with a standardized coefficient of $0.32(p<0.001)$, meaning that $\mathrm{H} 1$ was not supported. The results indicated that work schedule flexibility was positively related to turnover intention. The current study also revealed that this factor was highly positive and adequately fit the model. Furthermore, an organization would need to ensure that it can decrease turnover intention through practices focused on work schedule flexibility to improve working conditions from those such as a busy schedule and a high workload. Meanwhile, employees with an unsatisfactory perception of a job increase turnover intention.

H2 was supported, predicted that financial reward would have a negative effect on turnover intention. The findings of this study imply that financial rewards may be strong predictors of turnover intention because the relationship was found to be significant. Meanwhile, the findings suggest that the financial rewards provided to employees have the most dominant effects on decreasing turnover intentions. While financial rewards are recommended, professional nurses who perform well expect good pay, incentives, or promotions. Therefore, turnover intention may increase if they do not receive those financial rewards, which confirmed the findings in previous literature (Kahn \& Byosiere, 1992; Rhoades et al., 2001; Allen \& Griffeth, 2001).

The results revealed that the path showed a positive effect on turnover intention and was significant, with a standardized coefficient of $0.14(p<0.05)$, meaning that $\mathrm{H} 3$ was supported. Therefore, the results indicated that job demand was positively related to turnover intention. The current study also revealed that this factor had a high potential to effect turnover intention. Job demand adequately fit the model, which is supportive of previous studies (Kahn \& Byosiere, 1992; Karasek, 1997; Karasek \& Theorell, 1990; Adams \& Bond, 2000; Gurney, Mueller, \& Price, 1997; Bartram, Joiner, \& Stanton, 2004).

H4 was supported, indicating that job demands had a negative influence on turnover intention and were mediated through work engagement. This suggested that the effect work engagement adequately fit the hypothesis model. In addition, the results confirmed the argument that high job demands of employees might be a significant factor if they could provide an expected level of work engagement related to the well-being of employees (Hu et al., 2011; Llorens et al., 2006). Therefore, the hypothesis model of work engagement affected an employee's intention to stay at that workplace.

Because H5 was supported, perceived organizational support had an influence on turnover intention through work engagement. This path expressed that perceived organizational support indirectly affected turnover intention, because work engagement was negatively correlated and significant. These results suggested that perceived organizational supports improved work engagement and reduced turnover intention. An examination of Figure 2 indicates that employees who have positive perceived organizational support are less likely to have work engagement problems and have a lower turnover intention. Moreover, perceived organizational support appeared to explain the relationship between favorable work engagement and turnover intention. Workers who are emotionally committed to the organization present heightened performance, decreased absenteeism, and a lessened possibility of quitting their job (Mowday et al., 1982).

H6 was not supported, revealing that the high and low levels of perceived organizational support were not intermediary factors between job demands and work engagement. Rather than observing the moderation of perceived organizational support, moderation exists between job demand and work engagement. This finding 
did not confirm the contingency approach that emphasized that an organization with high levels of perceived organizational support was expected to have superior work engagement and subsequently reduced turnover intention compared with those with low levels of perceived organizational support. Indeed, top management, who is most likely to provide developmental opportunities, tends to devote more attention to employee's perceived organizational support in the workplace. Nonetheless, the difference in magnitude was considerable between the two groups. Therefore, it is not adequate to say that the relationships in the conceptual model are different between the two groups. This finding did not support the argument that when top management is committed to support employee retention with clear perceived organizational support, the organization reduces turnover intention or improves performance (Bailey, Berg, \& Sandy, 2001; Huselid, 1995).

H7 was supported, predicted that work engagement has a negative relationship with turnover intention. The findings of this study implied that work engagement could be a strong predictor for turnover intention, because the relationship between them is significant. Work engagement may result in improved turnover intention only when those organizations meet the expectations of the employees' needs. Furthermore, a significant negative relationship was found in the relationship between work engagement and turnover intentions, which confirmed the findings of the previous literature (Sak, 2006; Hallberg \& Schaufeli, 2006; Schaufeli \& Bakker, 2004; Harter et al., 2002).

There is a general consensus regarding the importance of work schedule flexibility, financial rewards, job demands, perceived organizational support, and work engagement as mechanisms to help workplaces (including hospitals) maintain turnover intentions. Also, the job demands of hospitals have relatively high negative effects on work engagement. Employees have to show willingness in a situation where there are negative feelings and strained and reduced engagement. The study also noted that job demands were negatively correlated with work engagement, and low imposed demands could create negative effects on turnover intention, thereby decreasing the turnover intention of employees. Employers could decrease turnover intention of their employees by decreasing job demand. The current research findings suggested that high level perceived organizational support on work engagement and job demands does not ensure that the level of turnover intention of professional nurses will be reduced. The study demonstrated that employees' high level of perceived organizational support could not assure better work engagement results of the hospitals. Instead of focusing on employees' engagement, other benefits related to the organization's turnover intention were highlighted in the current study. The positive effects of perceived organizational support in employees' practice may be due to the certainty of the impact of the situation regarding the levels of perceived organizational support of hospitals. Finally, the organization needs to know that focusing on work schedule flexibility and good working conditions (i.e., addressing busy schedules and high workloads) as well as financial rewards will ensure a decrease in turnover intention. The findings of this study suggested that financial rewards have the most dominant effects on decreasing turnover intentions.

The main practical contribution of this study was to help the workplaces (hospitals) maintain turnover intentions based on their human resource. The organizations could place more emphasis on improving and strengthening the demand they make available to their workforces in order to increase job engagement as well as take valuable inputs from employees on what kind of improvements they may need in perceived organizational support available to them. Finally, the organizations could also hire more educated individuals and proactively promote the better support to higher job levels in order to enhance their engagement with their jobs. Moreover, turnover intention could be predicted from the employees' response to work opportunities for 
perceptions of being valued and cared by supervisors. Professional nurses may need to place greater emphasis on the recruitment and selection process to ensure a greater organizational fit to help address in the issue of turnover among professional nurse in the private hospitals industry.

\section{Limitations of the Study}

The organizations in this study were selected because their characteristics varied in terms of organizational size, location, and type of health care and medical tourism. It is possible that there are particular characteristics of the hospitals that may influence the research findings differently if several other different hospitals are included.

\section{Future Research}

The results of the study generally provided several ideas for future research. However, due to the work of the organization, the levels of the job demands of employees (which have different conditions near the boundaries of the industry), the quality of work life balance, and its influence on outcomes should be investigated further. Future studies should investigate the relationships among these constructs. Additionally, employees from other cultures and identities that may reflect differences should be analyzed.

\section{References}

Adams, A., \& Bond, S. (2000). Hospital nurses job satisfaction, individual and organizational characteristics. Journal of Advanced Nursing, 32(3), 536-543.

Allen, D. G., \& Griffeth, R. W. (2001). Test of a mediated performance-turnover relationship highlighting the moderating role of visibility and reward contingency. Journal of Applied Psychology, 86(5), 1014-1021.

Bailey, T., Berg, P., \& Sandy, C. (2001). The effect of high performance work practices on employee earnings in the steel, apparel, and medical electronics and imaging industries. Industrial and Labor Relations Review, 54(2A), 525-543.

Baltes, B. B., Briggs, T. E., Huff, J. W., Wright, J. A., \& Neuman, G. A. (1999). Flexible and compressed workweek schedules: A meta-analysis of their effects on work-related criteria. Journal of Applied Psychology, 84, 496-513.

Bartram, T., Joiner, T. A., \& Stanton, P. (2004). Factors affecting job stress and job satisfaction of Australian nurses: Implications for recruitment and retention. Contemporary Nurse, 17(3), 293-304.

Beehr, T. A., \& Glazer, S. (2005). Organizational role stress. In J. Barling, E. K. Kelloway, and M. Frone (Eds.), Handbook of work stress (pp. 7-34). Thousand Oaks, C.A.: Sage Publications.

Bishop, J. W., Scott, K. D., \& Burroughs, S. M. (2000). Support, commitment, and employee outcomes in a team environment. Journal of Management, 26, 1113-1132.

Byrne, B. M. (2001). Structural equation modeling with AMOS: Basic concepts, applications, and programming. New Jersey: Lawrence Erlbaum Associates.

Byrne, B. M. (2004). Testing for multigroup invariance using AMOS graphics: A road less traveled, Structure Equation Modeling A Multidisciplinary Journal, 11, 272-300.

Byrne, B. M. (2010). Structural equation modeling with AMOS: Basic concepts, applications, and programming (2nd ed.). New York: Routledge.

Cook, J. D., Hepworth, S. J., Wall, T. D., \& Warr, P. B. (1981). Experience of work: A compendium and review of 249 measures and their use. New York: Academic Press.

Demerouti, E., \& Cropanzano, R. (2010). From thought to action: Employee work engagement and job performance. In A. B. Bakker and M. P. Leiter (Eds.), Work engagement: A handbook of essential theory and research (pp. 147-163). UK: Psychology Press.

Demerouti, E., Bakker, A. B., Nachreiner, F., \& Schaufeli, W. B. (2001). The job demands resources model of burnout. Journal of Applied Psychology, 86, 499-512.

Dessler, G. (1999). How to earn your employees' commitment. Academy of Management Executive, 13, 58-67.

Eisenberger, R., Huntington, R., Hutchison, S., \& Sowa, D. (1986). Perceived organizational support. Journal of Applied Psychology, 71, 500-507. 
Fornell, C., \& Larcker, D. F. (1981). Evaluating structural equation models with unobservable variables and measurement errors. Journal of Marketing Research, 18, 39-50.

Frone, M. R., Russell, M., \& Barnes, G. M. (1996). Work-family conflict, gender, and health related outcomes: A study of employed parents in two community samples. Journal of Occupational Health Psychology, 1, 57-69.

Gostick, A. R., \& Elton, C. (2007). The carrot principle: How the best managers use recognition to engage their people, retain talent, and accelerate performance. New York: Free Press.

Gurney, C., Mueller, C., \& Price, J. (1997). Job satisfaction and organizational attachment of nurses holding doctoral degrees. Nursing Research, 46, 163-171.

Hallberg, U., \& Schaufeli, W. B. (2006). Same but different: Can work engagement be discriminated from job involvement and organizational commitment. European Psychologist, 11, 119-127.

Harter, J. K., Schmidt, F. L., \& Hayes, T. L. (2002). Business-unit-level relationship between employee satisfaction, employee engagement, and business outcomes: A meta-analysis. Journal of Applied Psychology, 87, 268-279.

Hu, Q., Schaufeli, W. B., \& Taris, T. W. (2011). The job demands-resources model: An analysis of additive and joint effects of demands and resources. Journal of Vocational Behavior, 79, 181-190.

Huselid, M. A. (1995). The impact of human resource management practices on turnover, productivity, and corporate financial performance. Academy of Management Journal, 38, 635-672.

Kahn, R. L., \& Byosiere, P. B. (1992). Stress in organizations. In M. D. Dunnette and L. M. Hough (Eds.), Handbook of industrial and organizational psychology (2nd ed., Vol. 3, pp. 517-650). C.A.: Consulting Psychologists Press.

Kahn, W. A. (1990). Psychological conditions of personal engagement and disengagement at work. Academy of Management Journal, 33, 692-724.

Kahn, W. A. (1992). To be fully there: Psychological presence at work. Human Relations, 45, 321-349.

Kanchanachitra, C., Lindelow, M., Johnston, T., Hanvoravongchai, P., Lorenzo, M. F., Huong, L. N., ... dala Rosa, J. F. (2012). Human resources for health in Southeast Asia shortage, distributional challenges, and international trade in health service. Health in Southeast Asia 5 Series, 377, 769-781. Retrieved from http://www.thelancet.com

Karasek, R. A., Brisson, C., Kawakami, N., Houtman, I., Bongers, P., \& Amick, B. (1998). The Job Content Questionnaire (JCQ): An instrument for internationally comparative assessments of psychosocial job characteristics. Journal of Occupational Health Psychology, 3, 322-355.

Karasek, R. A. (1985). Job content questionnaire and users guide. Los Angeles: Department of Industrial and Systems Engineering, University of Southern California.

Karasek, R. A. (1997). Demand \& control model: A social, emotional, and physiological approach to stress risk and active behavior development. Encyclopedia of Occupational Health and Safety Volume II (4th ed.). Geneva: International Labor Office.

Karasek, R. A., \& Theorell, T. (1990). Healthy work: Stress, productivity, and the reconstruction of working life. New York: Basic Books.

Llorens, S., Bakker, A. B., Schaufeli, W. B., \& Salanova, M. (2006). Testing the robustness of the job demands-resources model. International Journal of Stress Management, 13, 378-391.

Major, V. S., Klein, K. J., \& Ehrhart, M. G. (2002). Work time, work interference with family, and psychological distress. Journal of Applied Psychology, 87, 427-436.

March, J. G., Guetzkow, H., \& Simon, H. (1958). Organizations. New York: Wiley\& Sons.

Maslach, C. (1998). A multidimensional theory of burnout. In C. L. Cooper (Ed.), Theories of organizational stress (pp. 68-85). UK: Oxford University Press.

Maslach, C., \& Jackson, S. E. (1986). Maslach burnout inventory (2nd ed.). Menlo Park, C.A.: Consulting Psychologists Press.

Ministry of Public Health. (2005). Thailand health profile 2005-2007. Nonthaburi: Bureau of Policy and Strategy.

Mowday, R. T., Porter, L. W., \& Steers, R. M. (1982). Organizational linkages: The psychology of commitment, absenteeism, and turnover. C.A.: Academic Press.

Pagaiya, N., \& Noree, T. (2009). Thailand's health workforce: A review of challenges and experiences. Washington, D.C.: World Bank.

Rhoades, L., \& Eisenberger, R. (2002). Perceived organizational support: A review of the literature. Journal of Applied Psychology, 87, 698-714.

Rhoades, L., Eisenberger, R., \& Armeli, S. (2001). Affective commitment to the organization: The contribution of perceived organizational support. Journal of Applied Psychology, 86, 825-836. 
Roodt, G., \& Jacobs, E. (2008). Organizational culture of hospitals to predict turnover intentions of professional nurses. Health SA Gesondheid, 13, 63-78.

Rosin, H. M., \& Korabik, K. (2002). Do family friendly policies their promise? An investigation on work-family conflict and work and personal outcomes. In D. L. Nelson and R. J. Burke (Eds.), Gender, work, stress, and health. D.C.: APA Books.

Rothausen, T. J. (1994). Job satisfaction and the parent worker: The role of flexibility and rewards. Journal of Vocational Behavior, 44, 317-336.

Sak, A. M. (2006). Antecedents and consequences of employee engagement. Journal of Managerial Psychology, 21, 600-619.

Schaufeli, W. B., \& Bakker, A. B. (2004). Job demands, job resources, and their relationship with burnout and engagement: A multi-sample study. Journal of Organizational Behavior, 25, 293-315.

Schaufeli, W. B., \& Salanova, M. (2007). Work engagement: An emerging psychological concept and its implications for organizations. In S. W. Gillilalnd, D. D. Steiner, and D. P. Skarlicki (Eds.), Managing social and ethical issues in organizations (pp. 135-77). C.T.: Information Age.

Schaufeli, W. B., Martinez, I., Marques Pinto, A., Salanova, M., \& Bakker, A. B. (2002). Burnout and engagement in university students: A cross-national study. Journal of Cross-cultural Psychology, 33, 464-481.

Simoens, S., Villeneuve, M., \& Hurst, J. (2005). Tackling nurse shortages in OECD countries. Retrieved from http://www.oecd.org/health/healthpoliciesanddata/34571365.pdf

Srisuphan, W., Senaratana, W., Kunaviktikul, W., Tonmukayakul, O., Charoenyuth, C., \& Sirkianokwilai, N. (1998). Supply and requirement projection of professional nurses in Thailand over the next two decades: 1995-2015. Human Resources for Health Development Journal. Retrieved from http://www.moph.go.th/ops/hrdj/Hrdj5/HRDJ2.3/WICHIT11.PDF

Stinglhamber, F., \& Vandenberghe, C. (2003). Organizations and supervisors as sources of support and targets of commitment: A longitudinal study. Journal of Organizational Behavior, 24, 251-270.

Trevor, C. O., Gerhart, B., \& Boudreau, J. W. (1997). Voluntary turnover and job performance: Curvilinearity and the moderating influence of salary growth and promotions. Journal of Applied Psychology, 82, 44-61. 